\title{
Menakar Loyalitas dan Volatilitas Pemilih Pada Pemilu 2004
}

\author{
Sobirin Malian
}

Generally, democracy is measured based on the level of people's participation to vote in general election. The higher perticipation, the higher level of democracy. This is, actually, not completely true. In the New Order Era, the participation to vote is extremely high, but, as has been proven by many research, this is far from democratic, because their participation was mostly done due to the despotical pressure. So, the demosracy will only happen if such high participation made by awarness and freedom, in democratic political atmosphere with full enforcement of legal norms. In the next general election, it seems that democratic instrument will be made, and therefore, people free to choose and change their political afiliation.

$\mathrm{N}$ ilai klasik demokrasi umumnya ditakar dari seberapa besar kesadaran rakyat berpartisipasi dalam memberikan suaranya pada sebuah Pemilu. Semakin besar suara yang diberikan, maka semakin dianggap demokratis sebuah Pemilu. Sebaliknya semakin sedikit suara yang diberikan maka partisipasi warga masyarakat dianggap rendah, dan nilai demokrasipun diragukan, benarkah demikian? Pernyataan ini tak sepenuhnya benar, karena sebuah partisipasi masih tergantung juga pada sistem politik yang dikembangkan.

Di masa Orde Baru partisipasi masyarakat dalam memilih sangat tinggi, karena saat itu rakyat merasa takut jika tidak memilih. Resiko lain dapat dituduh macam-macam seperti "anti Pancasila" dan lain-lain jika menolak memilih. Selain itu, sistem politik yang dikembangkan saat itu adalah sistem politik otoritarian yang dikemas dengan sandaran ideologis yaitu demokrasi Pancasila. Dengan pernyataan tersebut ingin dinyatakan bahwa partisipasi suara yang diberikan rakyat sangat tergantung pada sistem politik yang dikembangkan. Jika memang sistem politiknya demokratis dan ditopang oleh hukum yang ada, ukuran partisipasi suara yang besar dapat menjadi ukuran demokratisnya sebuah Pemilu. Dalam konteks inilah ukuran partisipasi itu akan ditakar melalui tulisan ini.

\section{Problem Era Reformasi}

Gerakan reformasi semula direspon sangat positif. Masyarakat banyak berharap warna politik ekonomi akan berubah ke arah yang lebih baik, tidak seperti sebelumnya. Namun, setelah reformasi memasuki tahun ke enam saat ini, harapan nampaknya tinggal harapan. Kebebasan berpendapat dan berpolitikmemang tumbuh subur, namun penegakan hukum, perbaikan ekonomi, rasa aman ternyata tak kunjung menghampiri. Bahkan Nurcholish Madjid menilai, di era 
Presiden Megawati aspek penegakan hukum, praktek KKN dan kondisi ekonomi tidak menunjukkan perbaikan, yang terjadi justru di sana-sini terlihat lebih jelek dari era Orde Baru.' Realitas tak ada kemajuan itu membuat sebagian masyarakat menjadi frustrasi.

Kefrustrasian ini semakin hari semakin bertambah yang mendorong. politik berada dalam siatuasi dan kondisi yang krusial dan krisis. Dalam kondisi demikian muncul pertanyaan besar dari kalangan masyarakat, apakah eksistensi bangsa ini akan tetap berlanjut atau justru akan semakin terpuruk setelah Pemilu 2004 ini. Terlebih Pemilu juga dibayang-bayangi dengan masuknya unsur-unsur anarki, kekerasan politik, dan praktik-praktik yang tak beradab lain yang belakangan muncul seperti, saat penyerahan daftar Caleg saja sudah nampak bibit-bibit dampak negatifnya. ${ }^{2}$ Memang diakui beberapa pengamat, Pemilu 2004 dianggap Pemilu yang sangat menentukan masa depan bangsa, dan jika gagal termasuk dalam memilih Pemimpin maka akan semakin sulit bagi bangsa ini untuk bangkit. ${ }^{3}$

Tampaknya jalan menuju kehidupan demokratis bagi bangsa ini memang masih panjang dan menyimpan bom waktu yang siap meledak sewaktu-waktu. Salah satu bom waktu itu adalah sulitnya memprediksi siapa yang akan keluar sebagai pemenang dalam Pemilu mendatang dan bagaimana nasib bangsa ini selanjutnya.

Ciri "ketidakjelasan arah" yang dialami seperti ini sebenarnya bukan hanya terjadi di Indonesia. Menurut Mainwaring, pengamat politik Latin, ciri sejenis itu sebenarnya melekat juga pada negara-negara yang sedang memasuki masa transisi seperti di Amerika Latin, ${ }^{4}$ oleh karena itu rasa frustrasi sebagian masyarakat itu dapat dimaklumi.
Dari hasil sebuah studi di Amerika Latin menunjukkan. bahwa $73 \%$ rakyat di 17 negara Amerika Latin menyatakan frustrasi dengan tatanan kehidupan yang mereka jalani selama masa transisi ke arah politik demokratis yang lebih pasti. Begitu juga yang terjadi di Rusia dan negara-negara di Afrika Barat. Lebih dari $60 \%$ warga di negara-negara itu mengalami frustrasi yang hebat akibat perubahan politik dari sistem otoritarian ke arah demokrasi. ${ }^{5}$

Menurut Romero, masa transisi sesungguhnya adalah masa yang sangat krusial. Masa transisi biasanya berkaitan dengan tiga hal pokok yaitu: (1) banyaknya unjuk rasa dan konflik sosial akibat ledakan partisipasi politik setelah sekian lama terkekang; (2) berkembangnya rasa tidak aman dalam masyarakat; dan (3) ketidakmampuan pemerintah transisi dalam mengatasi berbagai konflik (management of conflict). Ketiga hal itu saling terkait yang membuat masyarakat merasa kehidupannya menjadi penuh ketidakpastian. Jika kondisi ini tidak segera dapat diatasi bahkan terus berkembang, maka yang akan terjadi

- 1. Jawa Pos, 19 Januari 2004.

2. Di Surabaya, massa PDIP pro kontra menyambut penyusunan daftar Caleg, juga massa PKB di Jawa Timur, Golkar di Makasar dan PAN di beberapa daerah. Ini masih ditambah dengan adanya indikasi para Caleg memalsukan ijazah dan merekayasa susunan Caleg seperti di DIY dan lain-lain.

3. Hariman Siregar dan Nugroho Djayoesman meyakini Pemilu 2004 ini akan terjadi kekacauan karena itu mereka lalu membentuk kaukus penyelamat Pemilu.

4. Scott Mainwaring and Timothy Scully (eds), Building Democratic Institution: Party System in Latin America, Stanford,CA:Stanford University, 1995, hlm.18.

5. Romero dalam Joumal of Democracy, 1996. Ohio University. 
adalah konflik berdarah, anarkisme dan keterpurukan di berbagai bidang. Dalam wacana politik kondisi demikian ini digambarkan sebagai consolidated anarchy atau dalam terminologi O'Donnel sebagai "fase perubahan ke arah yang tak jelas." Masa ini ditandai dengan sistem politik yang mengalami "turbulensi" dan involusi politik yang kemudian melahirkan ketidakpastian, sinisme, anarkisme, berbagaj tindak kekerasan politik bahkan separatisme, dan disintegrasi yang ujung-ujungnya akan membawa kita ke arah otoriterian baru dengan cirinya yang militeristik.

Bagi Indonesia atau tepatnya elit politik, Pemilu 2004 ini merupakan sarana strategis didalam meredam berkembangnya consolidate anarchy tadi. Atas dasar itu elit politik tadi lalu merigusung konsep consolidate democracy dengan Pemilu sebagai titik 'tolaknya. Menurut O'Donnel dan Schmitter, sistem politik menuju consolidate democracy mengutamakan konsep problem solving (pemecahan masalah) dimana management of conflict dapat dilakukan secara efektif. Di sini setiap aktor politik atau konflikkonflik dasar yang berkembang dapat dilembagakan dan tidak "liar" di jalanan. Dengan demikian, setiap pelaku politik yang terlibat dalam konflik dapat dilerai dan bersedia mematuhi aturan yang sama yang disepakati sebagai aturan yang sah (the rule of law). Dari model inilah kita berharap Pemilu dapat berjalan lancar nantinya. Lalu jika kondisi Pemilu sudah kondusif, bagaimana dengan prospek dan karakteristik pemilih dalam Pemilu 2004 ini?

\section{Tentang Loyalitas}

Selama ini paling tidak ada tiga bentuk keputusan pemilih dalam menentukan partai yang ia pilih atau justru memilih untuk tidak memilih, tolok ukur ini tradisional sifatnya ${ }^{6}$ yaitu : (1) party identification; (2) issues of candidate and party; dan (3) candidate's (party elite's) personality, style, and performance. Identitas partai atau sering juga disebut loyalis partai. Mereka ini sangat menentukan keberhasilan sebuah partai terutama dalam sistem kepartaian yang telah mapan. Semakin solid dan stabil sebuah partai semakin mantap pula dukungan loyalis ini pada partai. Sebaliknya semakin kisruh srbuah partai akan berakibat serius terhadap kondisi psikologis para loyalis ini. Jadi, jika sebuah partai berubah warna akibat "perseteruan" di dalam maka secara langsung akan berakibat pula pada tingkat dukungan mereka. Terlebih di tengah suasana demikian bermunculan pula partaipartai baru yang dengan gencar menawarkan platform dan visinya. Gejala demikian ini dialami Jepang tahun 1993 dan Brasil tahun 1995. Dari sini dapat disimpulkan partaipartai besar yang rentan dengan gejolak itu akan berkurang dukungannya pada Pemilu mendatang, terlebih jika konflik intern ini tak mendapatkan penyelesaian secepatnya.

Pertimbangan kedua untuk menentukan perilaku pemilih dalam sebuah pemilihan adalah kemampuan partai dalam menjual isu-isu di saat kampanye. Partai hegemoni (status quo) pada rezim otoriter sudah terbiasa menjual isu-isu kemapanan dan keberhasilan yang mereka tempuh selama periode pemerintahan. Elit partai hegemoni ini dengan leluasa mengumbar janji-janji Pemilu yang belum tentu akan diwujudkan jika nanti mereka terbukti menang. Hubungan elit dengan pemilih ini mereka yakini bergerak dalam jalur patronclient. Selaku patron mereka merasa pasti akan selalu didukung oleh para klien apapun

6. Bambang Cipto, Partai, Kekuasaan dan Militerisme, Pustaka Pelajar, 2000. 
yang ditawarkan. Model demikian ini terlihat pada Golkar di masa Orde Baru dan PDIP saat ini. Bagi mereka dalam istilah Jawa,"pejah gesang nderek banteng" yang intinya ikut saja apa yang dikatakan elitnya.

Akan tetapi pada saat krisis menimpa, rezim otoriter seringkali mereka seperti kehilangan̉ arah dan bingung harưs menjual isu-isu apa. Hal ini akibat pamor mereka sedang berada di titik terendah. Dalam penelitian yang dilakukan Carolyn M Warner (1997) menemukan bukti-bukti menarik, bahwa hubungan patron-client bukan tanpa masalah, ketika dihadapkan pada gelombang reformasi. Justru yang tèrjadi kemudian partai-partai baru mendapatkan simpati, karena partai baru umumnya mampu menjual isu-isu menarik dan dianggap masih bersih terutama dari nuansa money politic. Partaipartai demikian ini terlihat pada Pemilu 1999 lalu dimana PKB dan PAN langsung berada pada posisi lima besar.

Pertimbangan ketiga adalah penampilan kandidat anggota legislatif (caleg). Di. negara-negara maju, pertimbangan inilah yang paling banyak menyedot perhatian masyarakat. Para caleg ini berlomba-lomba untuk dapat tampil secara prima dihadapan calon-calon pemilih dengan melakukan investasi besar-besaran di berbagai bidang. Di Jepang seorang kandidat dapat menghabiskan dana hingga mencapai 800.000 dolar AS untuk menyelenggarakan kampanye. Juga di Amerika, tidak sedikit dana dikeluarkan dari kocek untuk dapat tampil melebihi kandidat dari partai lain. Sukses Clinton dan Arnold Swachzenegger menjadi Gubernur California, salahsatu negara bagian AS, beberapa waktu lalu, antara lain karena ia tampak selalu tampil prima dalam setiap kesempatan, yang mampu menyihir para pendukung maupun lawannya.
Dalam konteks Indonesia, kandidat legislatif yang paling banyak disorot saat ini adalah masalah politisi busuk atau caleg busuk. Masyarakat nampaknya sudah jenuh dengan perilaku politisi yang hanya mempermainkan nasib rakyat. Mereka berharap Pemilu 2004 ini dapat memilih caleg yang bersih sehingga mampu mengubah keadaan ke arah yang lebih baik. Bagaimanapun performa calon sangat menentikan keberhasilan partai dalam merebut suara dalam Pemilu mendatang. Munculnya partai-partai baru tidak lepas dari kehadiran calon-calon yang jauh lebih menjanjikan dibanding politisi lama (apalagi yang dikenal busuk). Peran elit dan tokoh partai masih sangat menentukan dibanding lambang partai; para elit partai menentukan karena munculnya gejala volatility.

\section{Tentang volatility}

Volatility sering didefinisikan sebagai gejala pergeseran kesetiaan pemilih dari satu partai ke partai lain; dari pemilihan ke pemilihan lain ${ }^{7}$. Gejala ini mula-mula diidentifikasi dalam proses pemilihan di Amerika pada dekade 80-an ketika penggunaan televisi dan multimedia lainnya semakin tak terhindarkan dan bahkan sangat menentukan keberhasilan calon, khususnya calon Presiden AS. Eksploitasi teknologi televisi dan marketing untuk mengoptimalkan penampilan calon-calon presiden membuat keputusan pemilih menjadi tidak stabil.

Contoh menarik misalnya, ketika Jimmy Carter (Partai Demokrat) yang semula diunggulkan akan terpilih kembali menurut beberapa polling (TV dan Koran)

7. Scott Mainwaring, Multipartism, Robust Federalism and Presidentialsm in Brazil, 1997. Cambridge University Press, HIm.61-62. 
ternyata di saat-saat akhir sebelum pemilihan justru tertinggal jauh oleh Ronald Reagan. Reagan terpilih sebagai Presiden karena tim kampanyenya memahami dan memanfaatkan semaksimal mungkin sikap pemilih Carter yang tidak menentu sehingga menjadi massa mengambang (volatile and floating mass) akibat ulahnya yang kurang meyakinkan dalam menyelesaikan kasus penyanderaan diplomat AS di Iran.

Gejala volatilitas semacam ini ternyata juga muncul di dalam sistem partai di Amerika Latin yang sedang mengalami masa transisi. Di Brasil, pasca runtuhnya rezim militer diikuti dengan kemunculan berpuluh partai politik yang membuat partaipartai lama gulung tikar. Akibatnya volatilitas menjadi cukup tinggi, kendati muncul partaipartai baru yang visi dan misinya ada yang mirip dengan partai lama tak urung membuat pemilih menjadi mengambang. Yang paling menarik adalah kesimpulan Mainwaring bahwa akibat dari volatilitas kesetiaan pemilih membuat pola pemilihan di Brasil menjadi personalistic pattern of voting. Intinya, person atau elit partai menjadi jauh lebih menentukan dibandingkan dengan partai atau lambang partai. Hebatnya kalau kita bandingkan dengan kasus di Brazil, kondisi demikian ini mampu mengantarkan seorang calon Presiden dari partai kecil menjadi Presiden. Cardoso yang saat itu hanya didukung oleh partai kecil dan Collor de Melo yang muncul dengan partai baru sukses merebut kursi Presiden dalam Pemilu demokratis yang dipilih secara langsung.

Gejala ini sesungguhnya cukup dapat dimengerti mengingat kesetiaan pemilih yang tidak menentu akan menyebabkan pula sistem partai tidak menentu. Akibat lebih lanjut adalah orang (pemilih) cenderung lebih mempercayai elit puncak partai daripada partai itu sendiri. Dalam kaitan dengan pemilihan Presiden dan Wapres langsung pada Pemilu 2004 mendatang kekecewaan loyalis partai atas beberapa politisi busuk mungkin akan membuat mereka cenderung hanya memilih elit partainya dalam memilih Presiden dibanding caleg di tingkat DPR/ DPRD. Oleh karena itu jika Parpol kebetulan tidak memiliki tokoh yang dapat dipercaya untuk remilihan Presiden atau Wapres langsung (yang diidolakan) dan caleg yang bersih, maka partai tersebut akan kesulitan menempatkan wakilnya di legislatif.

\section{Kesimpulan}

Dari uraian tentang karakteristik pemilih ini dapat disimpulkan bahwa para pemilih loyalis terutama yang berbasis masyarakat tradisional akan tetap stabil terutama dari pendukung partai seperti PKB. Sementara pemilih volatilis akan cukup mengganggu perolehan suara dari partai-partai besar terutama partai Golkar, PDIP, PPP. Munculnya partai PNBK pimpinan Eros Djarot misalnya, diprediksikan oleh sebuah polling ${ }^{8}$ akan mampu mencuri 6 persen suara PDIP. Juga PNBK akan mampu mencuri suara PDIP sebesar 4,5 persen dan dari Golkar sebesar 10 persen suara. Beberapa partai baru ini memang hanya mengandalkan "limpahan" suara dari partai besar terutama yang terlibat konflik intern partai ${ }^{9}$ dan ketidaksepahaman dalam memasang nomor urut caleg antara pengurus parpol dengan konstituennya,

\section{Jawa Pos, 15 Januari 2004.}

9. Di daerah Sum-sel Khususnya Palembang menurut Kompas 6/2/2004 akan terjadi penurunan suara sigfikan yang dialami oleh PDIP, hal ini di karenakan konflik intern partai dengan kasus pemilihañ Gubemur telah menyebabkan para pendukungnya mengalihkan dukungannya ke PNBK atau PAN. 
namun demikian semuanya masih akan diuji pada riil suara pada Pemilu Maret-April mendatang.

Yang pasti dan harus dipahami bahwa akan terjadi perubahan signifikan akan makna Pemilu 2004 mendatang, dimana "ritual" itu sungguh-sungguh sebagai tanda political change. Pemilu kali ini menguatkan perubahan sistem partai dan sistem pemilihan langsung dan pola partisipasi masyarakat terhadap politik. Atas dasar demikian dalamnya makna yang terkandung, maka diperlukan elaborasi terhadap kemungkinan-kemungkinan yang baka! terjadi, dan dampaknya bagi partai-partai politik khususnya parpol-parpol baru.

Mengingat komitmen pasca Orde Baru adalah reformasi, maka dalam memilihpun seharusnya kita komit terhadap "ruh" reformasi itu, yakni menjadikan Pemilu sebagai arena "pengadilan" atau extra court bagi parpol-parpol (para elit politik) yang nyata-nyata tidak reformis. Dari perspektif ini, maka sikap pemilih dalam Pemilu nanti akan dilihat sebagai bentuk ganjaran (reward/compensation) dan hukuman (sanction). Pemilih selayaknya memberikan suaranya hanya kepada partai atau elit politik yang benar-benar mendukung reformasi. Dengan demikian hanya Parpol dan elit politik yang bersihlah yang akan mendapat suara terbanyak. Sebaliknya hukuman (sanction) akan ditimpakan kepada parpol atau politisi busuk yang jelas-jelas antireformasi. Sistem ganjaran dan hukuman ini sesungguhnya jauh lebih efektif (konkret) ketimbang hanya sekadar demo di jalanan atau sekadar dihujat di berbagai media.

Tentu akan ada beberapa kendala untuk mensosialisasikan makna "arena pengadilan" extra court ini karena sifatnya yang abstrak, terutama di daerah-daerah pedesaan yang tingkat pendidikannya rendah. Pemilih di daerah pedesaan yang kurang tersentuh oleh gema reformasi, tentu akan kesulitan membedakan mana partai yang reformis dan mana partai yang tidak. Kesulitan ini kemungkinan besar akan dimanfaatkan oleh politisi diaspora, yakni para politisi busuk yang membonceng partai sebagai kendaraannya. Efek langsung dari kendala ini adalah, partai baru yang reformis akan bersaing ketat dengan partai lama.

Sementara untuk di daerah perkotaan, politisi lama apalagi sudah dikenal sebagai politisi busuk akan kesulitan mendapatkan dukungan pemilih. Kota-kota besar di Jawa dan kota-kota besar di luar Jawa akan menjadi ladang subur bagi parpol-parpol reformis karena para pemilih boleh dikata sudah mampu membedakan secara "tepat" mana parpol dan politisi busuk dan mana yang reformis. Karena itu ganjaran berupa hukuman akan diterima oleh parpol-parpol yang telah gagal mengusung ruh reformasi.

Berdasarkan takaran di atas, maka 'Golkar dan PDIP plus PPP akan mengalami kesulitan terbesar di kawasan perkotaan terutama untuk pemilih muda. Diprediksikan ketiga parpol tersebut akan mengalami kesulitan dalam menangguk suara para mahasiswa, pelajar dan orang tua yang terdidik. Kalaupun mereka ingin meraih para pemilih muda tersebut, parpol bersangkutan harus pandai-pandai mengemas isu-isu kampanye dalam konteks posisi ideologis dan aspek universalitasnya. Persyaratan ini, menurut Bambang Cipto ${ }^{10}$, mutlak mengingat pemilih akan menuntut kemampuan parpolparpol tersebut dalam menggarișkan kebijakan program reformasi mereka.

Selain itu yang lebih memerlukan perhatian lagi, parpol-parpol baru dan parpolparpol reformis harus mengemas secara

10. Republika, 19 Februari 1999 
cakap penampilan dirinya dihadapan pemilih. Kebutuhan ini sangat penting karena mood pemilih yang tidak menentu dan massa mengambang (volatile and floating mass) akan cenderung menghasilkan pola pemilihan yang personalistik atau sangat bergantung kepada kepiawaian elit dalam berkomunikasi dengan para pemilihnya. Kepiawaian ini benar-benar harus menjadi andalan, mengingat menc'uri hati dan pikiran (hearts and minds) calon pemilih dalam kampanye sangat mutlak diperlukan. Tampaknya tidak semua parpol baru memilikinya, karena itu disarankan kepada parpol-parpol baru (kecil) tersebut untuk berkoalisi atau merger dengan parpol yang memiliki kelebihan tersebut. Dengan begitu akan terjadi kombinasi yang saling melengkapi.

\section{Daftar Pustaka}

Romero dalam Journal of Democracy, 1996. Ohio University.

Cipto,Bambang,2000, Partai, Kekuasaan dan Militerisme, Yogyakarta:Pustaka Pelajar.
Cipto, Bambang ,2003, Presiden, Partaidan Pemulihan Ekonomi Indonesia, Yogyakarta: UII Press.

Cipto, Bambang, 2003, Politik dan Pemerintahan Amerika, Yogyakarta: Lingkaran.

Mainwaring,Scott, 1977, Multipartism, Robust Federalism and Presidentialsm in Brazil, Cambridge: University Press.

Mainwaring, Scott and Scully, Timothy (eds), 1995, Building Democratic Institution: Party System in Latin America, Stanford,CA: Stanford University.

Gaffar,Afan, 2000, Politik Indonesia Transisi Menuju Demokrasi, Yogyakarta: Pustaka Pelajar.

Jawa Pos

Republika 